University of Rhode Island

DigitalCommons@URI

Open Access Master's Theses

1977

\title{
The Effects on Students When Cross-Age Teaching is a Part of the Classroom Procedure
}

Elaine Francas Arbor

University of Rhode Island

Follow this and additional works at: https://digitalcommons.uri.edu/theses

\section{Recommended Citation}

Arbor, Elaine Francas, "The Effects on Students When Cross-Age Teaching is a Part of the Classroom Procedure" (1977). Open Access Master's Theses. Paper 1374.

https://digitalcommons.uri.edu/theses/1374

This Thesis is brought to you for free and open access by DigitalCommons@URI. It has been accepted for inclusion in Open Access Master's Theses by an authorized administrator of DigitalCommons@URI. For more information, please contact digitalcommons-group@uri.edu. 
THE EFFECTS ON STUDENTS WHEN CROSS-AGE TEACHING IS A PART OF THE CLASSROOM PROCEDURE

$$
\text { by }
$$

$$
\text { Elaine Francas Arbor }
$$

A Thesis Submitted in Partial Fulfillment of the Requirements for the Degree of Master of Science in Home Economics Education University of Rhode Island 1977 
MASTER OF SCIENCE THESIS

of

Elaine Francas Arbor

Approved:

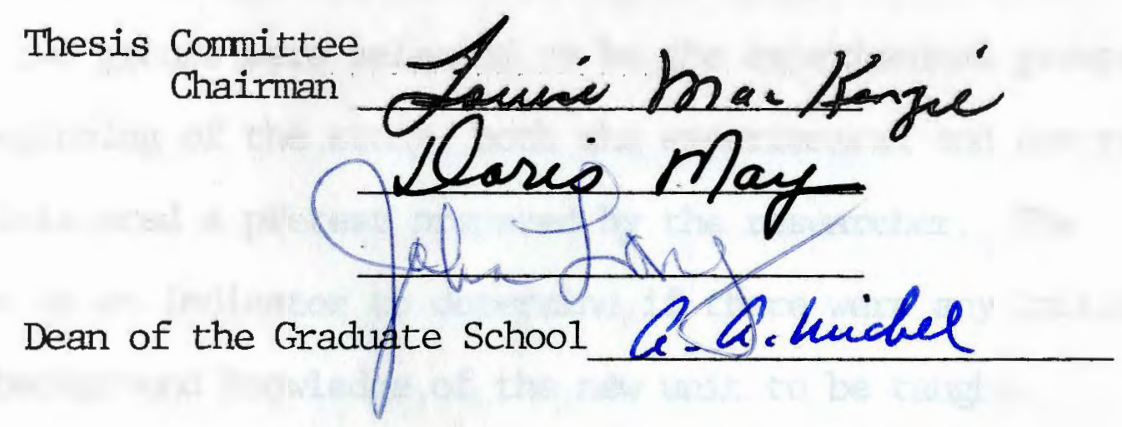

University of Rhode Island 


\section{ABSTRACT \\ THE EFFECTS ON STUDENTS WHEN CROSS-AGE TEACHING \\ IS A PART OF THE CLASSROOM PROCEDURES}

A comparison of Cranston High School East food and nutrition students was conducted to determine if achievement varied as a result of cross-age teaching.

The initial sample for this study was obtained by a random selection of sixty of the approximately one hundred twenty-five foods and nutrition students at Cranston High School East. The participants (students) were then further divided into four groups of approximately fifteen students. Two of the four groups were randomly selected to be the control and two groups were selected to be the experimental groups.

At the beginning of the study, both the experimental and control groups were administered a pretest prepared by the researcher. The pretest was used as an indicator to determine if there were any initial differences in background knowledge of the new unit to be taught.

The unit, "Preparing Nutritious Meals During Various Stages of the Life Cycle," consisting of twelve twenty-five minute lessons was taught ot all groups of students. Although students were told they were participating in an educational experiment to control for the "Hawthorne Effect", the experimental group was aware they were going to teach the subject matter to either a group of senior citizens or 
elementary school children. Participants in the experimental group were provided with two class periods to plan and finalize their lessons and visuals and two class periods to teach while the control group received review instructions during these four class periods. Frequently used review methods for the control group included nutritional games, discussions, written computation, oral presentation, debates, and audio-visual aids.

An objective post-test on food and nutrition developed by the researcher was used as the indicator of achievement. The post-test was reviewed and revised for content validity by two Cranston High School East food and nutrition teachers, two home economics education associate professors at the University of Rhode Island, and one nutritionist from the Food and Nutritional Science Department.

Using the two-tailed t-test for independent samples, the mean obtained by the exeprimental and control groups were sufficiently different to reject the null hypothesis at the .01 level of significance. The Kuder-Richardson Rationale Equivalence Test for the posttest indicated a reliability of .83 .

This study provided evidence that high school students who have the opportumity to teach food and nutrition to others will learn more about nutrition information than students who have been taught by the traditional teching techniques. 


\section{ACKNOWLEDGEMENTS}

Appreciation and deep gratitude is expressed to the members of the researcher's Master's Committee for the time devoted to the development of this thesis. Special recognition is awarded to Mrs. Louise MacKenzie for her devotion, encouragement and guidance from the conception of the idea to the completed project. Her unique ability of believing in a student and making that student feel special greatly facilitated the accomplishment of this research report.

Special appreciation is extended to Miss Sarah A. Connors for her time and steadfast guidance in the writing and editing of this thesis. As a supervising teacher, her parting words are a constant reminder - "Be a dedicated teacher..."

Gratitude is expressed to Mr. Joseph Ventetuolo for his cooperation in implementing this study. 


\section{TABLE OF CONTENTS}

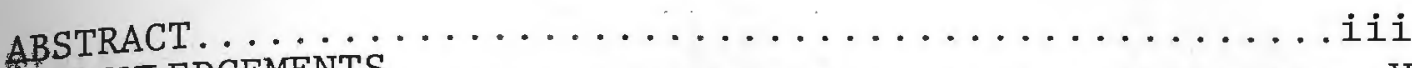

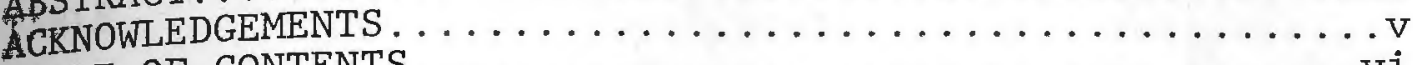

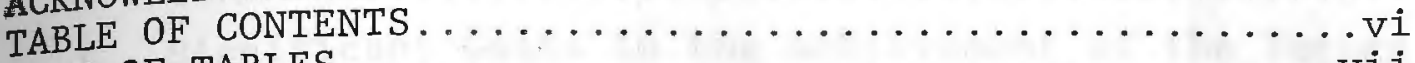

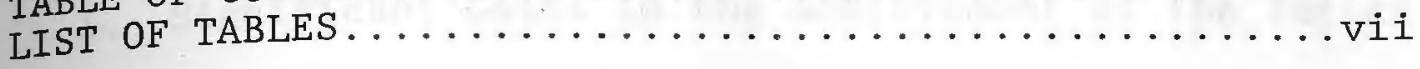

CHAPTER

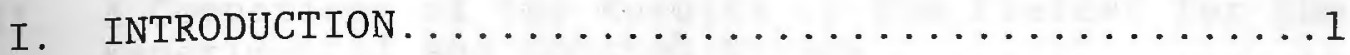

II. REVIEW OF LITERATURE..................

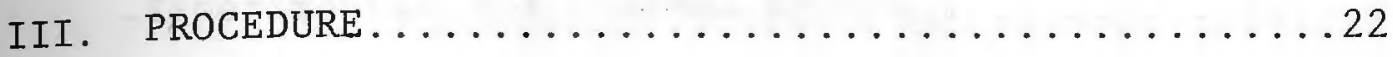



V. SUMMARY, CONCLUSIONS, AND RECOMMENDATIONS ......30 APPENDIX

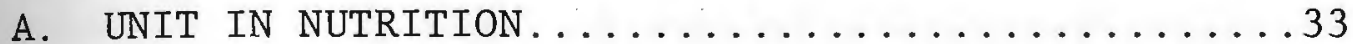

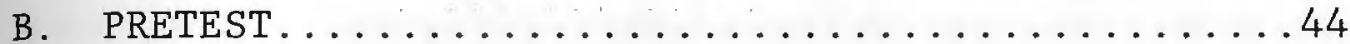

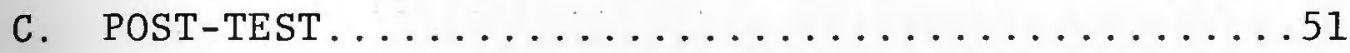

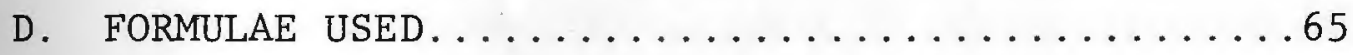

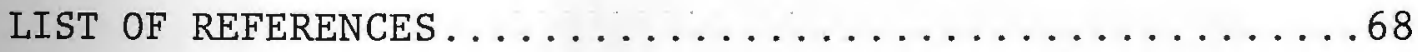




\section{LIST OF TABLES}

\section{TABLE}

I. Significant Gains in the Achievement of the Tutors..17

II. Design of the Study......................... 3

III. A Comparison of the Results of the Pretest for the Experimental and Control Groups..............28

IV. A Comparison of the Results of the Post-Test for the Experimental and Control Groups...............29 
CHAPTER I

TNTRODUCTION

Purpose

The purpose of this research study is to determine if there is a difference in the achievement of students in nutrition when taught by two methods of instruction. The experimental group of students actively participated in the planning and teaching of the subject matter to an outside group. The control group of students were taught by the same teaching method but received review lessons while the other classes plamned and engaged in cross-age tutoring experiences.

\section{Significance}

When students teach other students, a bond of responsibility is established between the classroom teacher and student, between one student and another, and between the student and tutee. This give and take relationship enhances the ego of the participant to produce a more desirable self-concept (Strodtbeck 1972). The cross-age tutor acts in an adult capacity, and this alters his perspective of the teaching-learning process. The tutor uses his skills to find a meaningful outlet to transfer his knowledge to another student and, in effect, he learns how to learn. Some other benefits of cross-age tutoring are better attendance records, fewer discipline problems, favorable acceptance by other age groups, becoming a productive part of society, meaningful use of classroom teaching, possible career orientation, breakthrough 
of commmication barriers between various age groups, and subject matter improvement. It has been said that "The individual learns better when he is doing than he does when he is listening to explanations by his teacher or is reading from his textbook. Interest is heightened when students begin to engage in concrete types of activity" (Davis 1966). There have been sufficient studies on tutoring to substantiate the general benefits of the tutorial cross-age teaching activity for the tutor. One might question whether these benefits would be derived from tutoring in any subject area. In a review of literature the researcher found virtually no supportive evidence to document the success of such tutorial cross-age teaching programs within home economics. Objective

The main objective of this study is to determine whether crossage teaching results in higher achievement compared to students who are taught by traditional review methods in a foods and nutrition course.

Sample

The participants for this study were four foods and nutrition classes taught by the researcher. The tutees were a second grade class at the Norwood Elementary School, and a senior citizen group at the Cranston Senior Citizen Center.

Two of the four foods and nutrition classes were selected at random to serve as the experimental group. The remaining two classes served as the control group. The second grade class and the senior 
citizens group served as the tutees. These two particular age groups were selected because of the importance of good food habits and nutritional information needed to build and maintain good health. Because of the need for good food habits in the early years of life, nutrition is an important concept for elementary school children to learn about. Elderly people, especially the poor, can benefit from increased nutritional information.

Definition of terms

For the purpose of this study, the following terms are defined for clarity and replicability:

Cranston East High School students--sixty tenth, eleventh, and twelfth grade students of food and nutrition in a local high school (Cranston East) who have been divided into two groups. One group will be taught via the traditional method (control group), and the experimental group will be taught to teach a group of people.

food and nutrition--a mini-unit lasting approximately twelve lessons, which is concerned with the subject of planning and preparing well-balanced and nutritious meals.

teaching--the act of guiding learners in acquiring knowledge in a specific subject matter or skill.

achievement--scores on teacher-made post-test received upon completion of teaching unit and analyzed statistically for significance. tutor--a student in the foods and nutrition class having some degree of special training who teaches others. 
cross-age tutor--a student in the foods and mutrition class having some degree of special training who teaches persons considerably younger or older than himself.

tutee--either the second grade student or the senior citizen. aged--The U.S. Department of Health, Education, and Welfare defines aged as "a concept which fixes the individual at a point in time, usually age 65. This arbitrary age is used, not because of an actual change that takes place in the individual, but because it has become the usual age of "retirement" in our society."

elementary school children--fifty students in a local grade school between the ages of seven and eight.

review techniques--methods of re-examining previously learned theories in order to reinforce the subject matter. Frequently used review methods include games, discussions, buzz groups, written computation, oral presentation, role-playing, and audio-vidual aids. Assumptions

1. The four foods classes chosen for the experiment are truly representative of the home economics population of the school.

2. The unit will be taught to both groups of students equally and without any biases.

Iimitations

1. The greatest limitation of this study will be its inability to be generalized to the entire student population at Cranston East, instead of applying solely to the home economics student population. 
Replication of this study with larger groups will be needed before attempting to synthesize the knowledge gained from this study with previous findings.

2. Class activities were scheduled with a predetermined time block and, therefore, were not very flexible.

3. In most tutoring situations there are four essential components: the tutor, the tutee, the learning medium, and the supporter. The context of this study was limited to the tutor. 
CHAPTER II

\section{REVIEW OF LITERATURE}

Throughout history people have employed tutors to teach the young. The wealthy made extensive use of this concept in educating their children. Gradually a new, less expensive, and more practical system was developed whereby students taught other students. According to Wright's account of Quintilian and Comenius (1960), younger children could learn more from their seniors in the same class. Eventually people began to look to the tutor as well as the tutee to document the findings of both parties involved in the teaching-learning process. In many instances, it was found that tutors learned more and developed a keener understanding and awareness of the subject matter than those being tutored. As far back as the 17th century, Comenius (16 ), an educator of the times, spoke out on the beneficial aspects teaching has on the tutor by saying:

He who teaches others, teaches himself, is very true, not only because constant repetition impresses a fact indelibly on the mind, but because the process of teaching itself gives a deeper insight into the subject taught... The gifted Joachim Fortius used to say that... if a student wished to make progress, he should arrange to give lessons daily in the subjects which he was studying, even if he had to hire his pupils.

Dillner (1972) makes reference to Andrew Bell in 1791 and Joseph Lancaster in the 1820's who also spoke out on the benefits of tutoring. However, most of their research was centered around the tutee. Bell and Lancaster share the credit for promoting the monitor- 
tal system in which the teacher would teach a group of students (later referred to as assistant teachers) and, in turn, these students would teach the same lesson to a group of other students. The Lancastrian system was brought to the United States in 1818 where it flourished as a means of mass education for the poor for about three decades.

During the same period, William Fowles published a book entitled Manual of Mutual Instruction. He delved one step beyond his predecessors in justifying this type of mass tutoring by mentioning the enormous benefits tutoring has on the person doing the teaching. Fowles conmented:

Teaching is learning, and learning of the very best kind. I appeal to teachers and ask whether every faithful attempt to teach their children under their care does not increase and improve their own knowledge... The art of teaching depends more upon adapting the explanation to the capacity of the learner than upon the amount of knowledge accumulated by the teacher. Is it umreasonable then to suppose that the explanations of children may sometimes be better suited to the understanding of children than those of adults would be: I am not ashamed to own that I often called upon my monitors to explain what I failed to make a little scholar apprehend" (Wright 1965).

Fowles gave every one of his students the opportunity to teach, even the lowest in intellectual capabilities because he felt everyone had something unique to contribute. 
From the 19th century to the middle of the 20th century there were few studies and reports published on tutoring. The studies available were comprised of honor students tutoring less competent students for the improvement of the tutees. Horst (1931-33) developed this type of program in conjunction with the high school student council where scholastically capable students tutored students of poorer pabilities. David (1938) and Wayne (1956) established a similar program through the honor society in the high school where they taught. Apart from these sparse studies during this time period in American educational history, it appears little was done in the area of tutoring and cross-age teaching until Lippitt and Lohman (1965) and Deering (1966) began more extensive studies. Emphasis was given to cross-age tutoring or teaching because it was a proven teaching method in effecting change in school systems where increasing student mobility was producing their toll in lower achievement levels.

As modern day pioneers, Lippitt and Lohman deduced the favorable outcomes of their experiment with tutors and tutees. Although the experimental group of tutors and tutees matched the control group on the California Achievement Tests, the McDaniel inferred and Self Concept scales and sociograms they exhibited more pronounced growth in academic learning, self-concept, social acceptability, self-discipline, and attendance than their control counterparts. These results can pasically be attributable to the fact that students acquire more 
knowledge of the subject by teaching the subject to others than if they were just taught the subject in a traditional setting. But why does this improvement take place? Lohman (1965) explains it further: "Being placed in a position of authority has an important motivational effect on the tutor; assisting other children helps the young tutor to develop, test, and internalize his own knowledge". Johnson (1969) supports this theory from a similar study and survey of teachers in which most reflected they learned more of their subject matter in the first year they had to teach it than in all previous years. It could be inferred that the teaching role prompted them to learn because of the freshly acquired responsibility assumed by the new role. Herbert Thelen (1969) mentions several contributing factors that may influence a student's ability to achieve higher in the teacher role:

...enhancing the ego support and self-esteem of the tutors, ...helping the students find a meaningful use of subject matter, thus assimilating it better and even coming to want more of it, ...giving children an opportunity to take an adult role, and to imagine what it would be like to be a part of the productive society... learning how to learn.

Hans Bhatia (1965) stated that a student will put his best foot forward when he finds the classwork useful and significant. This allows him to derive a maximum benefit from his learning and results in greater achievement. Anytime a student is an active partner in the learning enterprise, he will work harder and learn more. Billy Frances McClellan (1966) concluded from his extensive review of research that there are positive results of tutoring: 
1. ...Tutors experienced the development of their own sense of adequacy. Self-respect and self-esteem became realities for many individuals who previously saw themselves as non-contributing members of their class or group.

2. Tutors have found a meaningful use of subject matter...

3. Giving the tutor the opportunity to take an adult role and receive the status of teacher or helper leads him to experience what it is like to be part of a meaningful and productive society.

4. Tutors develop insights into the teaching-learning process and can cooperate much more effectively with their own teachers...

Lippitt and Lohman (1965) further explains the remarkable increase in a student's learning as he teaches others by the initiation of a rust-responsibility relationship. This relationship is motivating in itself,especially when acknowledged by an adult. Secondly, the tutor has a chance to work out some of his own difficulties, such as maturity in coping with his own abiliities and skills. The teaching situation can produce the desired awareness to penetrate these imer conflicts and adjust to a more realistic image of himself and what he may accomplish.

Another observation which helps to explain why tutors have an increased capacity for learning in the teaching role comes from a study by the National Commission on Resources for Youth, Inc. (1968) entitled 'Youth Tutoring Youth: It Worked; A Report of an In-School Neighborhood Youth Corps Demonstration Project." Results indicate tutors were spured on by their increased responsibilities and excitedly delved into the role of teacher in order to create a dynamic and creative teaching atmosphere. Tutors achieved a greater rapport with the younger children and, as a result, evidenced 
a change in their own self-esteem, especially after favorable comments from teachers, parents, and tutees. The experience of learning with the tutees and for the benefit of the tutees resulted in an increase in literacy skills for the tutor, and it was hypothesized that the experience of working with and teaching other children allowed the tutors to solve some of their own problems which helped give way to their increased learning skills. One person closely associated with the project interpreted the main outcome to be the change in attitude and increased maturity of the tutors even though literacy improved significantly.

Another study authored by Coleman (1974) entitled'Youth Transition to Adulthood" reported on the President's Science Advisory Conmittee. In the study, schools were investigated to determine how they effected youths transition to adulthood. It was found that schools need to radically change their teaching-learning environment in order to produce the desired atmosphere for change. According to Coleman, "Schools were found to be inadequate environments either for expanding the personal resources of students or for enabling students to assume responsibilities for others." Recommendations to produce the desired transtition to adulthood included having the students assume more responsibility, allowing the students to partake in activities which are personally satisfying for them, and working with other students of different backgrounds to produce shared objectives. Coleman's commission "...specifically recommends tutoring as an activity avorable to the growth of youth." As a result of this study, it can 
be theorized that much of the tutor's increased learning is the result of liking the new process of learning and the ability to relate to people from differing age levels and backgrounds to reach a cormon desired objective in addition to the overall increase in the tutor's -sponsibility, forcing him into an active role in the teaching-learning process.

An investigation of "Tutors in the Vanguard System", by Colosimo (1973) demonstrated that tutors in their newly acquired role as teachers learned a necessity for precision, the desirability of profound judgements, the importance of reliability and accepting responsibility in a meaningful and productive way which influenced reading levels in a positive manner.

A study initiated by Queens College in New York named Tutorial Community Report (1972) exhibits an increase in achievement level attributed to individualized instruction. Tutors contributed in the decision making process and shared in program planning which produced significant leadership development all favorable to higher achievement levels. Peggy Lippitt (1969) further explains tutors' increased achievement:

Students get a perspective on their own learning and ability, a more realistic picture of where they fit into the community of people, younger and older than thenselves...The older children help the younger children learn what the younger children want to know, and the younger children help the older children use their knowledge.

Active involvement on the part of the student is more conducive to learning than inert classroom behavior. It has also been stated by 
Davis (1966) that when students have engaged in a concrete activity, their understanding of the principles involved in the subject matter becomes more pronounced. In a comparison of two learning situations (one traditional, one experimental) students in the experimental group assumed responsibility for their class. This resulted in higher achievement of this group. Hans Bhatia (1965) concurs with Davis that "...the importance of active participation in classroom programs on the part of pupils makes for effective learning".

When fifth grade students tutored first grade students, they experienced a substantial increase in self-esteem. They also gained 1.9 years in reading scores over previous years, while discipline problens were reduced, cooperation of students increased, and interest in school heightened. Martha Dillner (1972) points out that "...through active involvement in helping another learn, the tutors learned to change their own attitudes toward learning and experienced the satisfaction of helping others."

In a similar experiment conducted by the Coumty School office (Landrum and Martin 1970), tutors' gains in achievement scores exceeded expectations. "The available data make it apparent that the tutor was more apt to attend school regularly, to obtain passing grades, and wentually to complete high school than those similar students who did not tutor." Apparently, the theory that teaching is a process of learning proved to be correct in this tutorial project. 
It has been said that (Davis 1966) "The individual learns better when he is doing than he does when he is listening to explanation by his teacher or is reading from his textbook. Interest is heightened when students begin to engage in concrete types of activity." The Kentucky State Department of Education (1972) is trying to stress a new movement in their school systems to allow students to actively participate in their classes by helping plan favorable student activities. The Department of Education feels that students who are instrumental in the planning and implementation of class activities should be a required portion of the curriculum, rather than a supplementary or, in most cases, a voluntary gesture.

Similar programs to those in Kentucky are springing up over all parts of the United States. According to Thompson (1972) Englewood, Colorado high school students take a special credited social studies course to learn material to teach to small groups of elementary school children. The purpose of teaching the material to the youngsters is so that the high school students can study the material in depth. The tutors have a chance to apply what they have learned while, at the same time, they have a chance to work with a different age group and explore their feelings and attitudes towards this group. As Thompson (1972) states: "Evaluation results indicate that the high school students have a lower absence rate during 
the semester ...; and there is a slight improvement in the overall grade point average of these students."

When students help others learn, the student has a sense of pride in that he is using his skills as a teacher to enhance the subject matter for others. David Klaus (1975) puts it this way "...academic gains for the tutor seem most likely when the tutoring experience obliges the tutor to work with and manipulate the instructional content."

Eva Conrad (1974) believes that teaching increases the knowledge of a student acting as teacher by forcing him to review previously leamed material to reformulate the material into effective teaching techniques. Both the tutors and tutees can learn in a cooperative rather than competitive atmosphere, and the tutors are active participants rather than passive learners. As Conrad states: "Considering the benefits of the tutor role, all children in a classroom regardless of achievement level should have an opportumity to be a tutor."

According to Dillner (1972), all participants must cooperate and work together to produce the desired teaching results, that is the tutor, tutee, and teachers of both sets of students. If this can be accomplished successfully, all should benefit.

These generalizations suggest that classroom teachers can take advantage of the effect of tutoring upon the tutor through the commalities that exist within the school curriculum, and can encourage tutors to acquire new skills. In tutoring the younger students, the tutor is provided with a unique opportunity to transfer such skills from a knowledge level to learning to an application of knowledge through the principle of learning through teaching. By cooperation at the teacher level, both groups would benefit with tutors gaining more from the experience than they have done in the past. 
It would seem when students are actively working together towards a goal they develop an interest that sparks their learning. Alice Crow (1972) said that the learner is likely to acquire a negative feeling towards his subject matter and learn little if he is not involved in determining the outcome of his learning activities. Therefore, the learner should be given opportunity to have real experience and to increase his comprehension of an application of the subject matter.

David Ausubel (1963) believed that active involvement of the learner in the subject area encouraged him to derive his own generalizations and synthesize new material.

Clifford Loomer (1953) said of the student:

He learns more thoroughly when he participates...than he does when he limits his activities to lectures and demonstrations. The individual learns best when he responds in a variety of ways to the materials at hand.

There have been many studies which substantiate this evidence. In Table 1 the results of seventeen studies are summarized to show ignificant gains for tutors in various academic areas. These tutorial gains indicate greater success than their control counterparts, which is due in large part to the tutor's motivation for his own review and Thanization of materials and ideas. The tutor is being placed in a position of authority and must prove himself adequate. In order to do this, he has to clarify those ideas that might otherwise have been rroublesome so that he may teach the concept correctly to others. The tutor's purpose in trying to come up with an interesting method of 
TABLE I

SIGNIFICANT GATNS IN ACHIEVEMENT OF THE TUTORS AS FOUND IN SEVENTEEN STUDIES

STUDY

*Allen (1972)

Brattman (1975)

*Cloward (1967) high school

*Hassinger (1967) high school

Herbert (1970)

*Lakin (1971)

*Liette (1971)

* Nahan (1971)

Moon and Wilson

(1970)

Morita (1972)

*Project S.T.E.P. (1975)

*Rosner (1970)

Schmucker (1974)

Sheretz (1970)

*Youth Tutoring high school Youth

Wilpert, Schroeder (1975)

\section{GRADE LEVEI}

5

6

IN ACHIEVEMENT

yes

yes

yes

yes

yes

yes

yes

yes

yes

yes

yes

yes

yes

yes

yes

yes

6

Wooten (1968)

yes
CONTENT AREA

academic achievement

reading

reading

reading

language

vocabulary, reading

reading

academic achievement

reading

reading

academic achievement

reading

academic achievement

reading, math, language

reading

vocabulary

language

NOIE: *Indicates significant academic gain for low achievers or disadvantaged youths. 
presenting the subject matter to the tutee is to sell the tutee the presentation, and by so doing, the tutor may sell himslef and master a keener awareness and heightened interest in the subject being taught. See chart, page 17 .

Bronfenbrenner (1973) thinks "the most urgent needed innovation in the American classroom is the involvement of pupils in responsible tasks on behalf of others within the classroom, the school, the neighborhood, and the community."

A White House Conference on Children (1970) recommends crossage teaching programs be continued and expanded. It was felt that such programs "... increase the learning capabilities of both participants...give the younger child an opportunity to identify with a significant other...enable the older youth to have a positive sense of accomplishment."

From the works of others it has been found that disadvantaged students and students of poorer capabilities are as effective in the teacher role as students of higher intellectual capacities. Allen (1972) feels that tutoring should not be limited to students of higher achievement only, that all types of students should have the opportunity to teach simply because teaching is such an effective learning technique. Refer to Table 1 and note that studies with asterisks show significant acaderic gains for low achieving disadvantaged youths.

Brown (1971) found that the principle of children learning from teaching other children even works with retarded children. "If 
tutoring is limited to a particular skill and specific tutoring task, inderachieving students can succeed as well as or sometimes better than adult or college students."

Lippitt (1969) found many slow learners to be more capable tutors than high achieving students, simply because they were more sympathetic to the learning difficulties slower achievers often had, and were better able to alleviate those problem areas. Stauffet (1967) concurs with Lippitt as stated in his findings "... it was found that both capable and less capable students functioned well as tutors; often the latter did best due to their greater sympathy for the tutee."

Tutoring as a means of improving achievement skills of disadvantaged youths is a relatively new concept. Upon evaluation of their experiment, Allen and Feldman (1972) conclude that tutoring may be a partieularly innovative method for motivating the academic performance of low achieving children.

A study completed at UCLA as reported by Frager and Stern (1970) opened new avenues to educators of low achieving students. Their study concluded:

Often when a tutoring program is initiated, teachers assume that only the most capable students should be used as tutors. However, this study has demonstrated that the achievement level of the tutor seems to make little difference in the amount of learning attained by the tutee, whereas there are significant differences in the gains made by the tutors. Thus, the findings of this investigation support the recommendation that low achieving students make effective tutors of younger disadvantaged children, and at the same time, profit considerably themselves. 
Thelen (1967) reported that Columbia investigated the theory futher and found children of slum areas to have increased 1.7 years in reading levels over their controls in a seven month period.

The idea of children learning through teaching is gaining in popularity throughout the nation. It is being experimented with in a variety of disciplines.

In Home Economics where heavy reliance on traditional teaching methods is not the usual situation, the opportunity for using this teaching-learning situation is quite opportume. For example, the need for nutritional knowledge at all levels is a fundamental requirement for healthy living. Because of the need for good food habits in the early years of life, nutrition is an important concept for elementary school children to learn about. Elderly people, especially the poor, can benefit from increased nutritional information. Students who participate in activities of this type are given a good opportunity to promote health and well-being and learn about their subject in a more relevant manner.

Although I have found various studies citing academic improvements in cross-age teachers, I have not been able to document any such studies within the Home Economics curriculum.

Benefits are so numerous for the tutor as well as the tutee it is hoped by the researcher to include more active classroom participation through the use of cross-age teaching. 
As Dr. Thelen (1969) so aptly puts it:

Today's new element is the anticipation of benefits to the tutor. It is hoped that he will develop his own academic skills or understanding further, as he employs them to teach another; that he will form a better character (e.g. attitudes), become better adjusted or more adequate as a person, discover new interests or comitments for his life. 
CHAPTER III

\section{PROCEDURE}

dased on a review of literature, it is not apparent that the effects of cross-age teaching on the home economics student have been tested. Further research is needed to determine if there is a difference in achievement of students in nutrition when taught by two methods of instruction, traditional versus cross-age teaching.

Sempling

The participants in this study were four of the foods and nutrition classes at Cranston High School East. A second grade class at Norwood Elementary School and a senior citizen group from the Cranston Senior Citizen Center served as the tutees in this study. The sample was selected because these four foods and mutrition classes were taught by the researcher and this would allow for greater uniformity during the teaching of the unit. The two outside groups were within easy access of the high school.

The initial sample for this study was obtained by a random selection of sixty of the approximately one humdred and twenty-five foods and nutrition students at Cranston High School East. The participants (students) were then further divided into four groups of approximately fifteen students each by the guidance department. Two of the four groups were randonly selected to be the control and two groups were selected to be 
the experimental groups. Instead of combining the two experimental groups, they were kept separate and the group to teach the elementary and aged were selected randomly.

Design

At the time of the pretest, all students participating in the study were informed that they were involved in an educational research project. This information was provided to control for the "Hawthorne effect." In addition, the experimental group was informed that they would be teaching outsiders. The same teacher (the researcher) taught both groups of students.

The design of the study can be diagrammed as follows:

TABLE II

DESIGN OF THE STUDY

Pretest

Group

Independent Variable

Post-Test

$\mathrm{Y}_{1}$

(R) $\mathrm{E}$

$\mathrm{X}$

$\mathrm{Y}_{2}$

(R) $\mathrm{C}$

$\mathrm{Y}_{2}$

Key to table:

(R) $\mathrm{Y}_{1}=$ all sixty students of sample

(R) $\mathrm{E}=$ randomly divided experimental group

(R) $\mathrm{C}=$ randomly divided control group

$\mathrm{X}=$ received experimental treatment

- = received no experimental treatment

$\mathrm{Y}_{2}=$ post-test results of two groups 
The experimental design was used as indicated in Table II. This particular design was selected because the population was a random sampling of foods and nutrition students at: Cranston High School East and because it allowed for as much control as possible under the circumstances.

The experimental and control groups were taught identical lessons for eight class periods. The experimental group planned for two class periods and taught for two class periods, while the control group reviewed instruction during these four lessons. Then, both groups of students were tested at the same time following completion of the unit.

\section{Instrumentation}

An objective, researcher-made, twenty-five question multiple choice pretest on nutrition was employed only as a means for determining any initial differences between the groups. It was not used as a measuring device for achievement.

A twelve lesson mini-unit, "Planning and Preparing Nutritious Meals During Various Stages of the Life Cycle" was taught by the researcher to all four foods classes. The experimental and control groups each received the same instruction for eight of the twelve lessons. The experimental group used two of the other lessons for plamning and preparing material to be used for the two teaching periods. In fact, some worked on teaching aids after school. The control group used the last four lessons for review purposes. 
An objective, researcher-made, sixty-six question multiple choice post-test on nutrition was used as the indicator of achievement. Prior to its administration, this post-test was evaluated for content validity by two Cranston home economics teachers, two associate professors of home economics education at the University of Rhode IsIand, and one professor of food and nutritional science. The consensus of their suggestions resulted in a slightly revised post-test which was deemed valid.

The principal provided the necessary scheduling changes to allow the researcher to administer the post-test to all participants at the same time. Absentees were able to make up the post-test with the researcher the following class period. After the post-test was administered and scored, the reliability of the test was determined by the KuderRichardson Rationale Equivalence test. This method was chosen because the test was administered once and measured a. single trait-achievement. The post-test was judged to be reliable.

Data Collection and Statistical Procedures

Upon computing the post-test scores, the mean of each group of scores was analyzed to determine any significant differences between the two groups of students. The absentee subjects who exceeded two class periods were not counted within the final analysis.

The two-tailed t-test for independent samples was used to compute the significance of the difference between the means of the two groups on the achievement scores. The result was evaluated at the .05 level of 
significance. This method for analyzing the data was chosen because the students were a random sampling of the home economics students population.

Budget and Time Schedule

This research project took place during the1976-77 school year. Resources for this research project were available to the researcher. The school principal assisted with bus transportation for the research project, thus eliminating any financial limitations.

\section{Significance}

It is hoped that the results of this research project will influence other home economists to modify their teaching methods in some areas to benefit the student. Home Economics is relevant to the student and the community members, and both groups working together can help one another.

Hypothesis

Based upon the method of student selection and the research design employed, the single research hypothesis to be tested in this study was: There is no significant difference in achievement of students in food and mutrition classes at Cranston High School East as a result of cross-age teaching. 
CHAPTER IV

\section{ANALYSIS OF DATA}

\section{Presentation}

The basic purpose of this study was to ascertain whether a significant difference in achievement would be attained as a result of students in food and mutrition classes at Cranston High School East who actively participate in planning and teaching the subject to others as opposed to students who are taught by the same method, but receive review lessons in place of actual teaching activity. Group Equivalency

A multiple choice test on nutrition was given to both groups of students, which indicated to the researcher that both groups of students initially were not statistically different in background knowledge in nutrition. The results of the tèst, as can be seen by examining Table III, indicate that there was no significant difference between the experimental group and the control group on the nutrition pretest, after using the t-test to compute the results. The t-ratio yielded a result of .76 , which at 57 degrees of freedom is not significant at the .05 level of significance for a two-tailed test. 
TABLE III

A COMPARISON OF THE RESULTS OF THE PRETEST FOR

THE EXPERIMENTAL AND CONTROL GROUPS

Number Mean $\begin{array}{llll}\text { Standard } & \text { Degree } & & \\ \text { Deviation } & \text { Freedom } & \text { T-Ratio Probability }\end{array}$

$\begin{array}{lllllll}\text { Experimental } & 28 & 13.86 & 2.71 & 57 & .76 & \text { NS* } \\ \text { Control } & 31 & 13.35 & 2.35 & & & \end{array}$

*Evaluated at the .05 level of significance, for which a ratio of 2.0 would have been significant.

Post-Test Validation

The researcher-made post-test consisted of sixty-six multiple choice items. The test questions were equally divided according to the importance given to each of the five major objectives. The validity of the test was ensured by ranking the test questions against the objectives. The Kuder-Richardson Rationale Equivalence test was used to estimate the reliability of the post-test, tabulated at .83 . Analysis

The two-tailed t-test was employed to find the difference in the two means. The results of the post-test are presented in Table IV. The experimental students who tutored younger or older people out-performed the control students who received normal review instruction 
by a difference of six points in the mean score on the post-test. The $t$-ratio yielded a result of 3.0 , which at 48 degrees of freedom is significant at the .01 level of significance for a two-tailed test.

TABLE IV

A COMPARISON OF THE RESULTS OF THE POST-TEST FOR THE EXPERTMENTAL AND CONTROL GROUPS

$\begin{array}{llll} & \text { Standard } & \text { Degree } & \\ \text { Number Mean } & \text { Deviation } & \text { Freedom } & \text { T-Ratio Probability }\end{array}$

\begin{tabular}{lllllll} 
Experimenta1 & 23 & 54.65 & 4.8 & 48 & 3.0 & .01 \\
Contról & 27 & 48.96 & 8.85 & & & \\
\hline
\end{tabular}

\section{Interpretation}

The amalysis of data concluded that there was a significant difference in the achievement of the students who taught others from the achievement of the students taught using traditional methods, this difference favoring those who engaged in cross-age tutoring. The null hypothesis can be rejected since a relationship between the independent variables in cross-age teaching exists. 
CHAPTER V

SUMMARY, CONCLUSIONS, AND RECOMENDATIONS

Sumary

The purpose of this study was to determine if cross-age teaching would yield higher achievement scores for the tutors than the traditional teaching methods would yield for the students of the control group. Four equivalent groups of home economics students taught by the researcher were randomly separated into the experimental and control groups. The students in the experimental group became the tutors in the study. A second grade class at the Norwood Elementary School and agroup of senior citizens at the Cranston Senior Citizen Center were the tutees for the experimental group.

In order to control for the "Hawthorne effect", all participating students, upon completion of the pretest, were informed that they were involved in an educational study.

A twelve lesson mini-unit, "Plaming and Preparing Nutritious Meals During Various Stages of the Life Cycle," was taught to all participants. The experimental group devoted four of the twelve lessons to planning and teaching this material to an outside group. The control group devoted four of the twelve lessons to review sessions. The posttest was administered to all participants at the same time. To the best of the researcher's abilities, all other factors remained constant. 
Conclusions

Using the two-tailed t-test for independent samples, the mean score of the experimental group was significantly higher than the mean test score of the control group at the .01 level of significance. The researcher concluded that the cross-age tutoring/teaching method of teaching and learning is more effective for the students than the traditional method of teaching. Test results indicated that the higher achievement scores of the experimental groups were a direct result of the teaching method (student involvement) and not based on a chance happening.

The results of this study applied only to the sample chosen from the limited population available to the researcher. However, the researcher's hope is that, as a result of the successful test results and reliability factor of the cross-age tutoring/teaching activity, other home economics teachers will adopt this teaching method to benefit the students. Since so many of the courses taught in home economics are also relevent to the comminity at large, there would be an eager tutee population with whom the classroom student could work.

\section{Recommendations}

Although this study did prove to a significant level that cross-age tutoring/teaching did improve the tutor achievement scores, it would be interesting to determine if the age level was a factor. Did the tutor relate more effectively to the younger or older tutee? What would influence this? It would also be interesting to test for 
attitudinal changes. Of great interest to the researcher is the retertion period for the material taught by both cross-age tutoring/ teaching versus the traditional method.

Because of the results found in this study, it is recommended that the study be duplicated using a larger population and more detailed evaluation techniques. In addition, a more detailed analysis could be incorporated to determine other outcomes. 
APPENDIX A 
PLANNING AND PREPARING NUTRITIOUS MEALS

DURING VARIOUS STAGES OF THE LIFE CYCLE:

A UNIT IN NUTRITION TAUGHT TO THE EXPERTMENTAL AND CONTROL GROUPS OF STUDENTS 
PLANNING AND PREPARTNG NUTRITIOUS MEALS

DURING VARIOUS STAGES OF THE LIFE CYCLE:

\section{A UNIT IN NUIRITION TAUGHT TO THE EXPERTMENTAL AND CONTROL GROUPS OF STUDENTS}

\section{OBJECTTVE I}

\section{Major Objective}

Given a list of the major nutrients necessary to maintain good health, the student must be able to recite at least two significant functions that each of those nutrients performs for the body.

\section{Generalization}

A knowledge of nutrients and their functions is necessary in making wise nutritional choices to meet the needs of your body. Concept

Identifying nutrients and their functions.

Activity

1. each student is given a booklet to read for home work, "Food is More Than Just Something to Eat"

2. teacher gives notes on nutrients and their functions

3. show film --"Food - A Supernatural Resource"

4. discuss booklet "Food is More Than Just Something to Eat"

5. for homework write a news article about a nutrient's function OBJECTIVE II

Major Objective

Given various dietary food plans, the student will be able to choose the most nutritious of the food plans in three out of four instances. 
Generalization

A healthy body is something that must be constantly maintained. one way to help your body stay attuned is by choosing nutritionally sound meals based on a knowledge of the nutrients and the foods that contain them.

Concept

Choosing a nutritious food plan.

Activity

1. plan a balanced day's menu around Dairy Council food model cards

2. break up into buzz groups - discuss why there are poor dietary habits and how to correct them

3. go up to resource center and discuss and choose three articles to read

4. listen to students' articles from resource center

5. discuss pamphlets on food requirements of older people and younger people

6. plan a balanced day's menu for a younger brother, a grandparent, and yourself

\section{OBJECTIVE III}

Major Objective

The student will be able to explain how to use nutritional labeling by listing the standardized format of nutritional food labels and state five advantages of using nutritional labels when marketing for food. 
Generalization

Since the Food and Drug Administration acted upon consumers' request to begin a widescaled program of nutritional labeling for all praducts making a nutritional claim, then consumers should learn how to best use this new information to their own advantage.

Concept

Learning to use nutritional information on food labels.

Activity

1. hand out cereal boxes - what's on a nutritional label?

2. give out handouts on mandatory and voluntary nutritional information - discuss

3. for homework, prepare a nutritional label for a new product OBJECTIVE IV

\section{Major Objective}

The student will be able to debate the issue "vitamin pills to take or not to take - that is the question" by listing at least three advantages and three disadvantages of taking vitamin pills. Generalization

A vitamin pill is an expensive price to pay for an inadequate diet.

Concept

Vitamin pills: standard merchandise or optional equipment? Activity

1. discuss vitamin pills - pro or con and debate issue 
2. for homework, write rambling paper on what you feel about vitamin pills

\section{OBJECTIVE V}

Major Objective

Given a list of various snacks, the student must be able to select and prepare those snacks that are most nutritious for children, teenagers, adults, and grandparents.

\section{Generalization}

Learning to select and prepare nutritious snacks for different aged family members is an integral part of nutritional meal planning. Concept

Selecting and preparing nutritional snacks.

\section{Activity}

1. prepare various nutritious snacks

2. discuss how snacks relate to various aged family members' needs 


\section{INDIVIDUAL LESSONS FOR "PLANNING AND PREPARING \\ NUTRITIOUS MEALS DURING VARIOUS STAGES \\ OF THE LIFE CYCLE"}

Lesson I

Students will receive notes on nutrients and their functions. For homework, students will read booklet "Food Is More Than Just Something To "Eat".

Lesson II

Students will view film "Food: A Super Natural Resource", and discuss it. For homework, students will write a news article about a nutrient's function.

Lesson III

Plan a balanced day's menu around Dairy Council food model cards. Students will then go up to the resource center to select three articles to read and discuss.

\section{Lesson IV}

Students will listen to articles from resource center, then discuss pamphlet on food requirements of older people. For homework, students will plan a balanced day's menu for a young brother, a grandparent, and themself.

\section{Lesson $\mathrm{V}$}

Students will break up into buzz groups to come wo with solutions to solve mutritional problems for case study people, then role play ways to explain to the people how they may change their nutritional habits. 
Lesson VI

Teacher will hand out cereal boxes to discuss what is on a nutritional label. Handouts will be given out on required and non-required nutritional information, then discussed. For homework, students will prepare a nutritional label for a new product.

Lesson VII

A. Students will plan lesson for teaching experience.

B. For review, students will play a nutritional password game.

Lesson VIII

Students will discuss vitamin pills pro and con by breaking up into two groups and debating the issue. For homework, students will write a "rambling on" paper expressing their opinions on vitamin pills.

Lesson IX

Students will prepare various nutritious snacks while discussing the importance of each's sontribution to different family member's diet needs. Lesson $\underline{X}$

A. Students will teach the first of their two teaching lessons.

B. Students will review a film on mutrition and discuss it.

\section{Lesson $\underline{X I}$}

A. Students will plan a lesson for their teaching experience.

B. As a review, students will prepare for a debate on all the material taken from the nutritional unit.

Iesson XII

A. Students will teach the second of their two teaching lessons.

B. Students will continue their debate. 
TTME BLOCK: "PLANNING AND PREPARTNG NUTRITIOUS MEALS DURING VARIOUS STAGES IN THE LIFE CYCLE"'

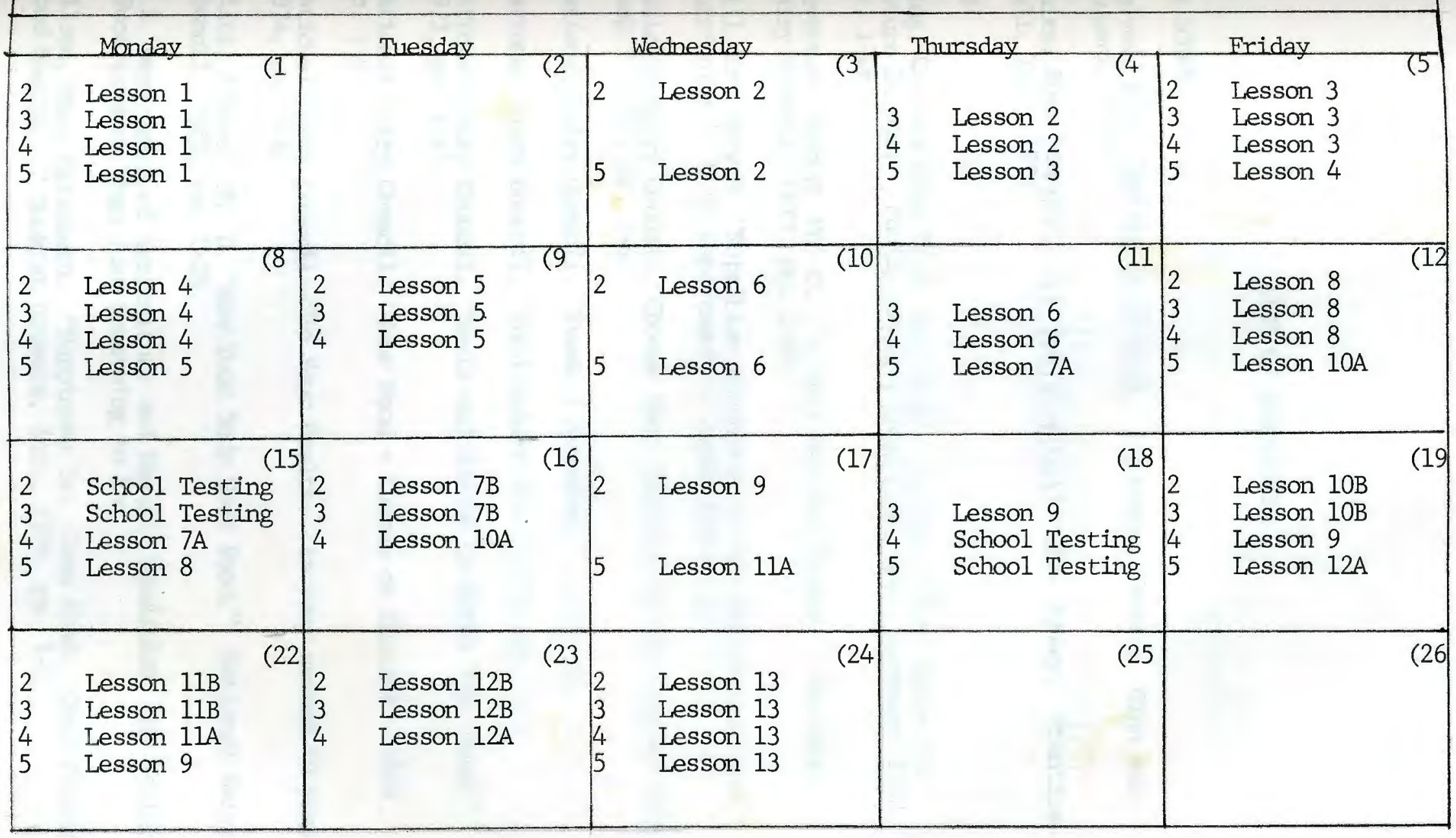

*Periods 2 and 3 indicate the control groups; Periods 4 and 5 inicate the experimental groups.

*Numbers in left hand margin of each block indicate respective class periods. 
LIST OF REFERENCES

REFERENCE BOOKS:

Melved, Eva. The World of Food. Lexington, Mass.: Ginn and Company, 1973.

White, Ruth Bennett. You and Your Food. New Jersey: PrenticeHall, Inc., 1971.

PAMPHETS :

King, Charles Glen Ph.D. and Britt, George. "Food Hints for Mature People." Public Affairs Committee, Inc., November 1962, pp. 1-28.

Leverton, Ruth M. Ph. D. "A Girl and Her Figure." National Dairy Council, 1973, pp. 1-24.

Hill, Dr. Mary M. 'Nutrition Education in the Elementary School Curriculum." U.S. Department of Agriculture, pp. 1-7.

National Dairy Council. "Choose Your Calories by the Company They Keep." 1975, pp. 1-4.

National Dairy Council. "Foods I Remember." 1958, pp. 1-4.

National Dairy Council. "Food Before Six." 1975, pp. 1-7.

National Dairy Council. "Meals and Snacks to Match Your Mood." 1973, pp. 1-11.

National Dairy Council. 'Your Food - Chance or Choice?" 1974, pp. 1-8.

National Dairy Council. "To Your Health... in your second 50 years." 1974, pp. 1-6.

Piltz, Albert, Ph. D. "How Your Body Uses Food." National Dairy Council, 1972, pp. 1-26.

U.S. Department of Agriculture and Health, Education, and Welfare. "Food is More Than Just Something to Eat."

Wilson, Mary Elizabeth. 'Happiness is: Good Food...Good Friends... Good Health..." Sumkist Growers, Inc., 1976, pp. 1-4. 
JOURNALS:

Ross, Margaret L. Ph. D., R.D. 'What's Happening to Food Labeling?" Journal of the American Dietetic Association. 64 (March 1974): pp. 262-267.

FIIMS:

"Food: A Super Natural Resource." Chicago: National Dairy Council and the Milk Foundation, Inc., 1975. 
APPENDIX B 


\section{PLANNING AND PREPARING NUTRITIOUS MEALS DURTNG}

VARIOUS STAGES OF THE LIFE CYCLE

\section{PRE-TEST}

Directions: Place the letter of the correct word or phrase that best answers each of the following items on the answer sheet provided.

1. Which is the most important mutrient necessary for all the processes of digestion?
A. vitamin $\mathrm{K}$
B. vitamin $\mathrm{A}$
C. water
D. vitamin $\mathrm{D}$

2. Nutritional labeling is voluntary except in one of the following products when the label must provide nutritional information. Which product?
A. salt substitute
B. macaroni
C. frozen orange juice
D. milk

3. Supplemental or therapeutic vitamins should be advised only by a:
A. druggist
B. physician
C. teacher
D. pharmacist

4. A teenage girl on the heavy side has a calcium intake deficiency. The best snack for her among the following is:
A. cream cheese and a bagel
B. blueberry yogurt
C. cottage cheese
D. cheese and crackers

5. The two most common vitamins found in fruits and vegetables are:
A. $A \& B$
B. $B \& E$
C. $B \& D$
D. $A \& C$ 
6. Strong bones and teeth require:
A. iodine
B. thiamine
C. iron
D. calcium

7. The RDA shown on nutritional labels refers to:
A. regulated dietary additives
B. recommended daily allowance
C. right dietary action
D. reduced daily allowance

8. If you were trying to reduce weight, which of the following snacks would you eliminate?
A. potato chips
B. carrot curls
C. cantaloupe
D. peaches

9. Enriched breads and cereals have had what vitamin restored to them?
A. A
B. thiamine
C. C
D. D

10. Excess amounts of fat-soluble vitamin pills will:
A. have no effect
B. reduce nervousness
C. reduce obesity
D. produce harmful effects

11. Which of the following nutrients is responsible for building and repairing?
A. protein
B. carbohydrate
C. fat
D. vitamin $\mathrm{K}$ 
12. Grandmother is putting on too much weight and you suggest she eliminate one of her more fattening and less nutritious snacks. Which one would you suggest she give up?
A. whole wheat crackers and jam
B. oatmeal cookies and milk
C. chocolate covered mints and punch
D. banana nut bread and tea

13. Carrots are rich in what vitamin?
A. A
B. niacin
C. C
D. D

14. Of the following people, who would be most likely to have an iron deficiency?
A. grandfather
B. your baby sister
C. your father
D. a teenage gir1

15. Which of the following vitamins are stored by the body?
A. riboflavin
B. vitamin $\mathrm{A}$
C. niacin
D. vitamin $\mathrm{C}$

16. If you lack sufficient amounts of thiamine in your body, the best possible solution among the following is:
A. continue to eat the same diet but take a vitamin B pill
$B$. do not worry about your diet, take an all-purpose vitamin pill
C. improve your diet to include higher intakes of vitamin $B$
D. add an apple to your daily diet

17. Which of the following claims does the Food and Drug Administration prohibit that might otherwise appear on nutritional labeling?
A. the list of ingredients in descending order of predominance
B. if the product contains additives
C. if the product is an imitation
D. that a balanced diet of ordinary foods cannot supply adequate amounts of nutrients


18. Incorporating which of the following into her grandfather's diet will provide the vitamin $\mathrm{K}$ needed?
A. spinach
B. carrots
C. yogurt
D. cauliflower

19. Iodized salt is needed for:
A. better complexion
B. prevention of goiter trouble
C. increasing the appetite
D. better flavor in food

20. Which of the following items on a mutritional label would not help you consume a better diet?
A. the eight key nutrients
B. comparison of food values
C. a picture of the product
D. the nutritive value of packaged convenience foods

21. Iron deficiency will cause what in the body?
A. anemia
B. low white cell count
C. aches in joint areas
D. toxic reactions

22. Which of the following kinds of orange juice has the most vitamin C?
A. fresh squeezed
B. frozen
C. camned
D. they have relatively equal amounts

23. One major function of vitamin $\mathrm{A}$ is to prevent:
A. diabetes
B. low blood sugar
C. night blindness
D. anemia 
24. How many mandatory nutrients must be expressed as a percentage of the U.S. RDA on nutritional labels?
A. 16
B. 8
C. 4
D. 12

25. How many servings from the meat group are needed each day?
A. 1
B. 2
C. 3
D. 4 
APPENDIX C 
PALNNING AND PREPARING NUTRITIOUS MEALS DURING

VARIOUS STAGES OF THE LIFE CYCLE

POST-TEST

Directions: Place the letter of the correct word or phrase that best answers each of the following items on the answer sheet provided.

1. Which of the following in not a function of vitamin $A$ ?
A. helps keep skin clear and smooth
B. helps control bone growth
C. helps keep mucous membranes firm and resistant to infection
D. helps to clot the blood

2. If the product makes a nutritional claim, then the ingredients must be stated on the nutritional label to justify such claim. Which of the following would be a nutritional claim?
A. grade A
B. low cholesterol
C. U.S. Choice
D. fresh daily

3. Four grandfather needs a nutritious snack that will help him with fonstipation problems. Which snack would you recommend?
A. one half cup blackberry ice cream
B. an apple
C. stewed prunes
D. a banana

4. Which of the following is a function of vitamin $\mathrm{C}$ ?
A. heals wounds and resists infection
B. aids energy production in cells
C. necessary to form hemoglobin
D. helps thyroid gland work properly 
5. To get a well-balanced diet, a person should:
A. follow the Basic Four
B. eat more than enough food at each meal
C. take vitamin pills
D. eat only when you feel like it

6. In which of the following cases would vitamin pills most likely be recommended?
A. obesity
B. pregnancy
C. hypertension
D. heart attack

7. If seafood is not readily available as a source of iodine, what could be substituted for it?
A. oranges
B. salt
C. iodized salt
D. sugar

8. Which piece of information is not required on a nutritional label?
A. serving size
B. calories
C. U.S. RDA
D. amount of drained weight

9. Which of the following would be a higher nutritious replacement for soda as a beverage?
A. cocktail
B. tea
C. coffee
D. milk

10. The main drawback of vitamins advertised in the media is:
A. they appeal to the age group - color and shape
B. lack of nutritional information
C. appealing flavor
D. hero or heroine related 
11. The two main minerals most likely to be inadequate in the diets of various age groups are:
A. calcium and iron
B. iodine and iron
C. flourine and iodine
D. phosphorous and sodium

12. Nutritional labeling will not benefit which of the following people?
A. persons interested in weight control
B. persons interested in spending more money
C. persons interested in trying new fabricated foods
D. people on sugar free diets

13. Carbohydrates provide the body with:
A. vitamin $\mathrm{C}$
B. fats
C. fuel and energy
D. red blood cells

14. Your little sister is always tired and has little energy. Which mutritious snack would you recommend?
A. an orange
B. a slice of bread with jam
C. a small bag of potato chips
D. a candy bar

15. An average man consuming about 2500 calories a day needs to consume about how much water each day?
A. 1 cup
B. 1 pint
C. 1 quart
D. 2 quarts

16. The RDA requirements shown on nutritional labels stand for:
A. the amount of nutrients reconmended for good nutrition
B. the minimum amount of nutrients to prevent deficiency diseases
C. the right deficiency amount
D. related dietary advice 
17. Which one of the following is a fat-soluble vitamin?
A. thiamine
B. C
C. A
D. niacin

18. Taking vitamin pills regularly will:
A. improve your dietary eating patterns
B. help you eliminate obesity
C. make you "feel better"
D. be an extra added expense

19. Vitamin $\mathrm{K}$ aids in:
A. helping blood to clot
B. building bones and teeth
C. prevention of night blindness
D. maintaining bright clear skin

20. Which of the following snacks would tend to have the least amount of calories?
A. rich snacks
B. watery-crisp snacks
C. greasy-crisp snacks
D. close-textured snacks

21. Which of the following foods provide the best source of vitamin C?
A. corn
B. cheese
C. tomato
D. macaroni

22. The purpose of the Food and Drug Administration in changing food labels was:
A. to increase the financial status of the products
B. to make infomation on food labels more meaningful to the public
C. to make labels more eye-catching for the consumer
D. to sell more food 
23. Excess amounts of water-soluble vitamins in your body will:
A. be eliminated and not used by the body
B. produce toxic levels
C. cause you to become nauseous
D. cause pernicious anemia

24. What nutrient helps prevent tooth decay?
A. potassium
B. protein
C. magnesium
D. flouride

25. Incorporating which of the following into her grandfather's diet will provide the vitamin $K$ needed?
A. spinach
B. carrots
C. yogurt
D. cauliflower

26. Which of the following nutrients does not have to appear on a nutritional label?
A. vitamin $\mathrm{C}$
B. thiamine
C. vitamin D
D. riboflavin

27. Which of the following snacks would be considered to be a low sugar snack?
A. vanilla wafers
B. cheese
C. whole wheat crackers and jam
D. sherbert

28. How many mandatory nutrients must be expressed as a percentage of the U.S. RDA on nutritional labels?
A. 16
B. 4
C. 12
D. 8 
29. If you lack sufficient amounts of thiamine in your body, the best possible solution among the following is:

A. improve your diet to include higher intakes of vitamin B

B. add an apple to your daily diet

C. continue to eat the same diet, but take a vitamin B pill

D. do not worry about your diet, take an all-purpose vitamin pill

30. Which of the following vitamins protects the vitamin A and carotene from destruction by oxidation?
A. $\mathrm{K}$
B. D
C. C
D. $E$

31. Grandmother is putting on too much weight and you suggest she eliminate one of her more fattening and less nutritious snacks. Which one would you recommend she give up?
A. whole wheat crackers and jam
B. banana nut bread and tea
C. chocolate covered mints and punch
D. oatmeal cookies and milk

32. Vitamin $\mathrm{C}$ is found in abundance in:
A. whole wheat breads
B. citrus fruits
C. milk products
D. most meats

33. Which of the following nutrients provides the most heat and energy to the body?
A. carbohydrate
B. protein
C. vitamin D
D. vitamin $\mathrm{K}$

34. Which of the following items on a nutritional label is not considered a part of the standard format set up by government regulations?
A. serving size
B. percentage of U.S. RDA
C. servings per container
D. drained weight 
35. Vitamin pills should be taken when:
A. all the nutrients have been removed from the food
B. grandmother cannot get enough iron rich foods because she can only eat strained foods
C. your friend wishes to go on a quick weight loss diet
D. you want to prevent a disease from occuring

36. One of the best sources of protein from among the following is:
A. fish
B. bread and butter
C. apple pie
D. gelatin

37. Nutritional labeling is mandatory in which of the following cases?
A. cream cheese
B. eggs
C. fortified milk
D. canned peaches

38. You have a terrible acne condition and your physician suggests you change your eating pattern. You are very hungry. Which snack would you choose?
A. french fries
B. vanilla ice cream cone
C. oreo cookies
D. potato chips

39. Which of the following items may appear on nutritional labeling?
A. that a product is fortified
B. that the cooking of a food may be responsible for an inade- quacy or deficiency of the daily diet
C. that a natural vitamin in a food is superior to a synthetic one
D. that a food has dietary properties when they are no significant value in human mutrition

40. The Basic Four refers to:
A. the four vitamins needed by humans
B. a diet required at least four days a week
C. the four nutrients needed by humans
D. the four groups of food needed every day by humans 
41. Strong bones and teeth require:
A. iodine
B. thiamine
C. iron
D. calcium

42. The body needs what vitamin to absorb the calcium supplied by food?
A. C
B. D
C. thiamine
D. niacin

43. A satisfactory substitute for meat is:
A. creamed peas on toast
B. macaroni salad
C. baked beans
D. fried egg plant

44. Nutrient labeling is defined as:
A. the fats, carbohydrates, and proteins in a particular food product
B. the standard of identity of a product
C. the major ingredients listed in descending order of predominance
$D$. the amount of certain major nutrients in an average serving of food

45. Your little brother has just broken his ankle and will be laid up for some time. Which snack will you try to feed him?
A. chocolate flavored milk
B. an apple
C. a banana
D. raw carrots

46. Green and yellow vegetables help you to:
A. see better at night
B. avoid the disease called rickets
C. have strong bones and teeth
D. build red blood cells 
47. A dark green vegetable should be eaten:
A. twice a day
B. once a week
C. every other day
D. once every two weeks

48. Which of the following claims does the Food and Drug Administration prohibit that otherwise might appear on nutritional labeling?
A. the list of ingredients in descending order of predominance
B. if the product contains additives
C. if the product is an imitation
D. that a balanced diet of ordinary foods cannot supply adequate amounts of nutrients

49. Excess amounts of fat-soluble vitamin pills will:
A. have no effect
B. reduce nervousness
C. may produce harmful effects
D. reduce obesity

50. Citrus fruits should be eaten at least:
A. once a day
B. twice a day
C. twice a week
D. once a week

51. Iron deficiency will cause what in the body?
A. low white cell count
B. anemia
C. aches in joint areas
D. toxic reactions

52. According to the Food and Drug Administration rules, nutritional labels may not imply:
A. the type of fat contained in certain foods
B. that a food can cure a disease
C. the number of calories in an average portion
D. the carbohydrate content in processed foods 
53. Carrots are rich in what vitamin?
A. thiamine
B. C
C. A
D. D

54. An empty calorie is:
A. 50-100 calories per ounce of food consumed
B. a unit of measure
C. a food low in calories
D. a food that has many calories and extremely low nutritive value

55. Which of the following items on a nutritional label would not help you consume a better diet?
A. the eight key nutrients
B. comparison of food values
C. the nutritive value of packaged convenience foods
D. a picture of the product

56. Choose the most nutritious snack from among the following for a pre-school age youngster?
A. whole wheat crackers and cottage cheese
B. oreos
C. Fritos corn chips
D. popcorn

57. Protein is most essential for:
A. energy
B. proper growth
C. vitamin enrichment of the diet
D. calories

58. The most important dietary reason for including salads in the diet is:
A. adds color
B. adds flavor
C. adds roughage to the diet
D. adds crispness to the meal 
59. If you are trying to reduce weight, which of the following snacks would you eliminate?
A. potato chips
B. peaches
C. cantaloupe
D. carrot curls

60. Boys from 16 to 20 years of age should have about this many calories a day.
A. 2400 calories
B. 3000 calories
C. 4500 calories
D. 5000 calories

61. The food element needed for red corpuscles in the blood is:
A. iron
B. riboflavin
C. niacin
D. calcium

62. The two most common vitamins found in fruits and vegetables are:
A. B and $E$
B. B and D
C. A nad C
D. A and B

63. Salt water fish is valuable for this mineral:
A. flouride
B. calcium
C. iron
D. iodine

64. Which of the following vitamins can you get sufficient amounts from sunlight?
A. thiamine
B. vitamin D
C. vitamin $\mathrm{E}$
D. vitamin $\mathrm{C}$ 
65. Among the following, the best comparison between natural and synthetic vitamins is:
A. natural vitamins are better for you
B. synthetic vitamins are less likely to produce side effects
C. there is very little difference between them
D. natural vitamins are absorbed more readily in the body

66. This nutrient yields $2 \frac{1}{4}$ times as much energy as other sources. What is it?
A. fat
B. protein
C. carbohydrate
D. minerals 
APPENDIX D 


\section{FORMULAE USED}

Source

Ary, Donald and Jacobs, Lucy Chesar and Razavieh, Asghar. Introduction to Research in Education. New


$108-109,136-137,208$.

Mean

$$
\bar{X}=\frac{\sum X}{N}
$$$$
\overline{\mathrm{X}}=\text { mean }
$$$$
\Sigma X=\text { sum of the measures }
$$$$
\mathrm{N} \text { =number of measures }
$$

\section{$\underline{\text { Standard Deviation }}$}

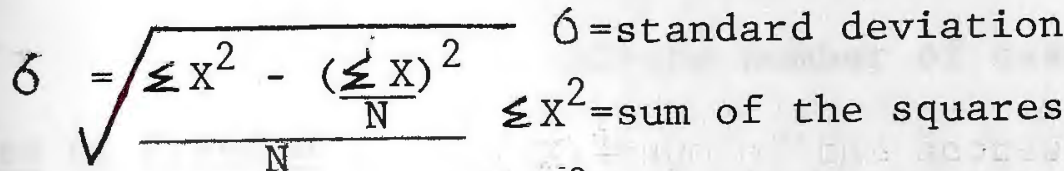

$$
\begin{aligned}
& (\Sigma \mathrm{X})^{2}=\text { sum of the scores squared } \\
& \mathrm{N}=\text { number of cases }
\end{aligned}
$$

Variance

$$
\begin{aligned}
& 6^{2}=\frac{x^{2}}{N} \\
& 6^{2}=\text { variance } \\
& \mathrm{X}=\text { the deviation of each score from } \\
& \text { the mean } \\
& \mathrm{N}=\text { number of cases }
\end{aligned}
$$


T-Ratio



$\overline{\mathrm{X}} 1-\overline{\mathrm{X}} 2=$ the observed difference between two means

$\leq X 1^{2}=$ the sum of the squared deviation scores in Group 1 $\begin{aligned} \Sigma x 2^{2}= & \text { the sum of the squared deviation } \\ & \text { scores in Group } 2\end{aligned}$

$\mathrm{N} 1=$ the number of cases in Group 1

N2=the number of cases in Group 2

Degrees of Freedom

$$
\begin{array}{ll}
\mathrm{DF}=\mathrm{N} 1+\mathrm{N} 2-2 & \mathrm{~N} 1=\text { number of cases in Group } 1 \\
& \mathrm{~N} 2=\text { number of cases in Group } 2
\end{array}
$$

Kuder-Richardson Reliability Test

$$
R 11=\frac{K X^{2}-\bar{x}(K-\bar{x})}{x^{2}(K-1)}
$$

RII=reliability of whole test

$\mathrm{K}=$ number of items in test

$2=$ variance of the scores

$\overline{\mathrm{X}}=$ mean of the scores 
LIST OF REFERENCES 


\section{LIST OF REFERENCES}

Allen, Dwight W. Students As Teachers. Education Cassette Series, No. 116. ERIC Document Reproduction Service, ED $041871,1970$.

Allen, D. W. and Gross, R. E. 'Microteaching: Stanford program wins 1965 distinguished achievement award for excellence in teacher education." National Education Association Journal. 54 (1965): $27-35$.

Allen, Vernon L., and Feldman, Robert S. Learning Through Tutoring: Low-Achieving Children as Tutors. Wisconsin: Eric Document Reproduction Service, ED 070 029, 1972.

Ausubel, David P. The Psychology of Meaningful Verbal Learning. New York: Grune and Stratton, $196 \overline{3}$.

Bell, S. E., Garlock, N. L., and Colella, S. L. "Students as Tutors." The Cleaning House. 44 (1969) : 242-244.

Bhatia, Hans Raj. A Textbook of Educational Psychology. New York: Asia Publishing House, 1965.

Bloom, Sophie. Peer and Cross-Age Tutoring in the Schools: An Individualized Supplement to Group Instructions. Washington, $\bar{D}$. C..: ERIC Document Reproduction Service, ED 118 543, 1975.

Brattman, Marvin A. Multigrade Helping Relationship Program: A Third Year Evaluation of the ESEA Title III End of Project Report. Chicago, I11. : ERIC Document Reproduction Service, ED 113692 , 1975.

Breedlove, Donnie L. Improvement, Supervision, and Dissemination of a Model Cross-Age Tutoring Program. Dallas, Texas: ERIC Document Reproduction Service, ED 117 048, 1975.

Bremmer, Barbara L. Students Helping Students Program, 1971-1972. Final Report. Seattle, Washington: ERIC Document Reproduction Service, ED 074 473, 1972.

Bronfenbenner, Urie. A Report on Longitudinal Evaluation of Preschool Programs. Is Early Intervention Effective? New York, New York: ERIC Document Reproduction Service, ED 093 501, 1973.

Brown, Lou, and Fenrick, Nancy. "Trainable Pupils Learn." Teaching Exceptional Children Fall (1971): p. 18. 
Cloward, R. D. Studies in Tutoring. New York: ERIC Document Reproduction Service, ED 021 903, 1969.

Cloward, R. D. "The Nonprofessional in Education." Educational Leadership 24 (1967) : 604-606.

Coleman, J. S. Report of the Panel on Youth of the President's Science Advisory Comittee. Youth: Transition to Adulthood. Chicago: University of Chicago Press, (1974).

Colosimo, Jerry. Tutors in the Vanguard System. Marlin, Texas: ERIC Document Reproduction Service, ED 075 528, 1973.

Conrad, Eva. Peer Tutoring: A Cooperative Learning Experience. Tucson, Arizona: ERIC Document Reprođuction Service, ED 108 747, 1974.

Crow, Alice Ph. D. Educational Psychology. Totowa, New Jersey: Little Field, Adams \& Co., 1972.

Dahlen, G. G. "High School Students as Elementary Teacher Aide." School and Commmity 57 (1970): 46.

Damico, Sandra, and Watson, Kathy. Peer Helping Relationships: An Ecological Study of an Elementary Classroom. Gainesville, Florida: ERIC Document Reproduction Service, ED 090 458, 1974.

David, A. I. "Student Tutoring: A Success at Collingwood High School." Clearing House 12 (1938) : 288-289.

Davis, Robert A. Learning in the Schools. Belmont, California : Wadsworth Publishing Company, Inc., 1966.

Deering, Albert R. Homework Helper Program Fact Sheet. New York, New York: ERIC Document Reproduction Service, ED 020 279, 1968.

Deering, A. R. The Development of the Mobilization for Youth Homework Helper Program: A Case Study New York, New York: ERIC Document Reproduction Service, ED , 1966.

Dillner, Martha Harriet. The Effectiveness of a Cross-Age Tutoring Design in Teaching Remdial Reading in the Secondary Schools. Gainsville, FIorida: ERTC Document Reproduction Service, ED 066 731, 1971.

Dillner, Martha Harriet. Tutoring by Students: Who Benefits? Gainsville, Florida: ERIC Document Reproduction Service, Ed 061 $150,1972$. 
Donahue, Oscar. Innovations in the Public Schools of Santa Clara County. Jose, California: ERIC Document Reproduction Service, ED 067 $752,1972$.

Enright, Robert D. A Social-Cognitive Developmental Intervention with Sixth and First Graders. Minneapolis, Minnesota: ERIC Document Reproduction Service, ED 199 841, 1975.

Ference, Camille. Participant Observers: A Low Threat Approach to Junior High Counseling. New York, New York: ERIC Document Reproduction Service, ED 112 338, 1972.

Titz-Gibbon, Carol Taylor. Improving Practices in Inner-City Schools: Two Contributions. Washington, D. C. ERIC Document Reproduction Service, ED 107 746, 1975.

Frager, Stanley and Stern, Carolyn. 'Learning by Teaching." Reading Teacher XXIII (February 1970): 417.

Gartner, Alan. Children Teach Children: Learning by Teaching. New York, New York: ERIC Document Reproduction Service, ED 056 157, 1971.

Hagan, John W., and Moeller, Tamerra. Cross-Age Tutoring. Arm Arbor, Michigan: ERIC Document Reproduction Service, ED 085 090, 1971.

Harrison, Grant Von. Training Students To Tutor. Santa Monica, California: Systems Development Corporation, 1967.

Hassinger, J.and Via, M. 'How Much Does a Tutor Learn Through Teaching Reading?" Journal of Secondary Education 44 (1969): 42-44.

Herbet, Charles Henry, Jr. Social Role and Linguistic Variation. Claremont, Ohio: ERIC Document Reproduction Service, ED $064268,1970$.

Holt, Jerry D. Comparison of Lecture-Demonstration with SelfInstruction as They Effect Cognitive Information When Developing psychomotor Skills in a Competency-Based Module. Tennessee: ERIC Document Reproduction Service, ED $096277,1973$.

Horst, H. M. "Experiment with Student Tutors." National Education Association Journa1 22 (1933) : 206.

Horst, H. M. "History of Student Tutoring at West High School, Akron, Ohio." Clearing House. 6 (1931) : 245-249. 
Johnson, S. R. Students as Teachers. New York, New York: ERIC Document Reproduction Service, ED 026 999, 1969.

Rentucky State Department of Education. Learning Through Student Activities. Frankfort, Kentucky: ERIC Document Reproduction Service, ED $072537,1972$.

Klaus, David J. Patterns of Peer Tutoring. Washington, D. C.: ERIC Document Reproduction Service, ED 103 356, 1975.

Kopp, Frederick S. Evaluation of the Youth Tutoring Youth Program. Atlanta, Georgia : ERIC Document Reproduction Service, ED $075560 ; 1972$.

Landrum, J. and Martin, M. "When Students Teach Each Other." Educational Leadership. 27 (1970): 446-448.

Liette, Eileen Evelyn. Tutoring: Its Effects on Reading Achievement, Standard-Setting and Affect-Mediating Self-Evaluation for Black Male Under-Achievers in Reading. Cleveland, Ohio: ERIC Document Reproduction Service, ED $059020,1971$.

Lippit, P. and Lippit, R. "Cross-Age Helpers." National Educational Association Journal 57 (1968): 24-26.

Lippit, P. and Lohman, J. "Cross-Age Relationships -- An Educational Resource." Children 12 (1965): 113-117.

Lippit, Peggy. "Children Can Teach Other Children." The Instructor 78 (1969): 41,99.

Lippit, Peggy. Cross-Age Helping Programs and Suggested Designs Which Have Worked Well in Cross-Age Helping Programs. Washington, D. C. : ERIC Document Reproduction Service, ED 108 086, 1975.

Lippit, Peggy. Students Teach Students. Bloomington, Indiana: ERIC Document Reproduction Service, ED 113 $296,1975$.

Loomer, Clifford. "A Study of Certain Effects of Three Types of Learning Experiences in Art as Revealed in the Drawings by Participants." Journal of Experimental Education 22 (1953): 65-102.

McClellan, Billie Frances. Student Involvement in the Instructional Process Through Tutoring. Tallahassee, Fla. : ERIC Document Reproduction Service, ED 055046 , 1971. 
McWhorter, K. T. and Levy, J. "The Influence of a Tutorial Program Upon Tutors." Journal of Reading. 14 (1971): 364-366.

Mohan, Madan. Peer Tutoring As A Technique for Teaching the Unmotivated. Fredonia, New York: ERIC Document Reproduction Service, ED 061 154, 1972.

Moon, M. and Wilson, D. "Teacher-Counselor Cooperation: Building Self Concepts and Confidence in Children." School Counselor 17 (1970): 364-366.

Muller, Nancy. Cross-Age Tutors. Lindsay, California: ERIC Document Reproduction Service, ED $105968,1974$.

National Commission on Resources on Youth, Inc. Youth Tutoring Youth: It Worked. A Report of an IN Schoo1 Neighborhood Youth Corps Demonstration Project. New York, New York: ERIC Document Reproduction Service, ED $030614,1968$.

National Commission on Resources for Youth, Inc. Youth Tutoring Youth: Supervisor's Manual. New York, New York: ERIC Document Reproduction Service, ED 028 992, 1968.

Patberg, Judythe A. Pearson. The Organization and Development of a Tutorial Reading Program for Junior High School Students. Minnesota: ERIC Document Reproduction Service, ED 106 763, 1974.

Pica, Teresa. Project S.T.E.P.: Seniors Tutor for Educational Progress. Connecticut: ERIC Document Reproduction Service, ED $120296,1975$.

Powel1, Barbara S. Children As Teachers: Stages in CrossAge Tutoring. Cambridge, Mass.: ERTC Document Reproduction Service, Ed 108 046, 1975.

Queens College. Tutorial Community Report. New York, New York: ERIC Document Reproduction Service, ED 102 064, 1972.

Robertson, Douglas J. The Effects of an Intergrade Tutoring Experience on Tutor Self-Concept. San Diego, California: ERIC Document Reproduction Service, ED 059 769, 1971. 
Rosner, H. Facets of a Cross-Grade Tutorial Program. Anaheim, California: ERIC Document Reproduction Service, ED 041 721,1970 .

Rossi, Timothy P. "HELP: Students Teach Students." Reading Improvement VI (1969): 48.

Schnucker, Robert. The Affective and Cognitive Gains Made By Students in an Auto-Tutorial World Civilization Course Compared With students Enrolled in a Traditionally Taught World Civilization Course. Kirksville, Missouri: ERIC Document Reproduction Service, ED 109 992, 1974.

Spache, G. D. Good Reading for Poor Readers. Champaign, I11.: Garrard Publishing Company, 1970.

Stallings, Jane. Relationships Between Classroom Instructional Practices and Child Development. Menlo Park, California: ERIC Document Reproduction Service, ED $110220,1975$.

Stauffer, R. G. "Would You Use Pupil Tutors?" Instructor 77 (1967): 35.

Thelen, H. Learning By Teaching. Chicago: Department of Education, University of Chicago, 1968.

Thelen, Herbert A. Report on the Humane Person Defined. St. Louis, Missouri: Presented at the Secondary Education Leadership Conference, (1967).

Thelen, H. "Tutoring By Students." School Review 72 (1969): $229-244$.

Thompson, Albert R. Cross-Age Teaching in the Social Studies. Boulder, Colorado: $\overline{E R I C}$ Document Reproduction Service, ED 077806,1972 .

U.S. Congress, Senate. Committee on Nutrition and Human Needs. Nutritional Needs of the Nation's Older Americans. 92nd Congress, 2nd session, June 14,1972 .

U.S. Department of Health, Education, and Welfare. Proceedings, 1970 White House Conference on Children. Report of Forum 3. Expressions of Identity: The school-Age Child. Washington, D.C. 
U.S. Department of Health, Education, and Welfare. U.S. Department of Social and Rehabilitative Service Administration on Aging. U.S. Government Printing Office, Washington, D.C.

Wayne, W. C. "Tutoring Service: A Project for Future Business Teachers." Journal of Business Education. 31 (1956): 330 .

Wolpert, Edward M. and Schroeder, Thomas S. End of Year Report Switzerland County-School Corporation: Learning Tutors Offer Instructional Assistance. Program Description and Evaluation. Washington, D. C.: ERI Document Reproduction Service, ED $111786,1975$.

Wooten, Vida Jo. Primary Creative Writing. Tyler, Texas: ERIC Document Reproduction Service, ED 025 506, 1968.

Wright, B. "Should Children Teach?" Elementary School Journal 60 (1969): 353-369.

Zajano, Nancy, and Hubbard, Donald W. Guiding Older Children as Tutors: A Report on the Field Test. Madison, Wisconsin: ERIC Document Reproduction Service, ED 114 359,197 